\title{
ZIKIR DAN KETENANGAN JIWA
}

\section{(Solusi Islam Mengatasi Kegelisahan dan Kegalauan Jiwa)}

\author{
Burhanuddin ${ }^{1}$ \\ ${ }^{1}$ Institut Agama Islam Muhammadiyah Sinjai, \\ Jl. Sultan Hasanuddin, No. 20 Balangnipa, Sinjai \\ E-Mail: burhanuddinbur@gmail.com
}

\begin{abstract}
Abstrak
Manusia dewasa ini banyak mengalami kegelisahan batin dan kegalauan jiwa. Problema hidup terlihat dan dirasakan dimana-mana, bukan saja karena kebutuhan meningkat dan persaingan hidup yang semakin kompetitif, tetapi karena ulah sementara pihak mengusik kedamaian dengan berbagai dalih atau menawarkan aneka ide yang saling bertentangan dan membingungkan. Hati dan jiwa yang gelisah bukan saja dimonopoli dan dirasakan oleh orangorang miskin tetapi juga oleh orang-orang kaya secara materi namun hampa dan kosong jiwanya. Dalam islam salah satu solusi untuk menghilangkan perasaan tidak tenang dan tidak nyaman adalah dengan berzikir mengingat kepada Allah dalam arti yang luas. Berkaitan dengan zikir sebagai penenang jiwa, hal tersebut telah disebutkan didalam Al-Qur'an dan hadis Rasulullah dalam berbagai tuntunan dan petunjuknya bahwa untuk mengatasi kegelisahan batin dan kegalauan jiwa. Islam telah memberikan solusi dari berbagai persoalan yang dihadapi oleh manusia termasuk kondisi psikologi yang tidak tenang, dan agar manusia merasakan ketenangan dan kedamaian dalam hati maka diperintahkan untuk berzikir kepada Allah swt. Dengan zikir dan doa, akan menumbuhkan sifat optimis dan percaya diri dan itulah yang dapat mengusir kegelisahan jiwa, karena itu, dewasa ini banyak pakar dan ilmuan yang berdasarkan hasil penelitian mereka telah membuktikan hal itu.
\end{abstract}

Kata Kunci: Zikir, Ketenangan Jiwa

\section{Pendahuluan}

Perkembangan abad modern ditandai dengan kemajuan ilmu pengetahuan dan teknologi, yang mendorong terjadinya perubahan yang positif bagi kehidupan manusia, namun juga disadari bahwa kemajuan dan perkembangan tersebut telah membawa dampak negative. Salah satu dampak negatif yang muncul adalah hilangnya keseimbangan jiwa manusia utamanya mereka yang hidup di kota-kota besar dan itu ditandai dengan banyaknya manusia yang mengalami kegelisahan batin dan jiwa yang gersang, yang terkadang berakibat stress dan frustasi dalam kehidupannya.

Kemajuan peradaban umat manusia sejatinya memberikan kebahagiaan yang lebih banyak kepada manusia disamping memberikan kemudahan-kemudahan dalam aktivitas manusia. Namun fakta menunjukkan hal yang tidak demikian adanya, bahkan ketenangan dan kebahagiaan ternyata semakin mahal dan sulit ditemukan oleh manusia 
modern saat ini. Hidup semakin sulit bahkan kesulitan material juga berimplikasi menjadi beban mental dan psikis, menimbulkan kegelisahan,ketegangan, bahkan tekanan perasaan yang berakibat munculnya berbagai penyakit kejiwaan seperti stress,defresi dan frustasi yang mendorong pelakunya menempuh jalan pintas mengakhiri hidupnya dengan jalan bunuh diri.

Perasaan tidak tenang dan tidak nyaman memang sering kali mengganggu manusia, baik bersifat internal seperti rasa takut akan terjadinya sesuatu dan rasa putus asaakibat tidak mendapatkan apa yang diharapkan. Secara eksternal juga manusia terkadang tidak nyaman akibat kalah bersaing dengan orang lain, tidak adanya jaminan keamanan dan keselamatan hidup atau masa depan yang suram berupa sulitnya mendapat pekerjaan yang layak atau kekhawatiran terjadinya pemutusan kerja. Karena itu, tidaklah mengherankan apabila perasaan tidak tenang itu bias mengakibatkan kegelisahan yang dapat mengakibatkan penyakit stress dan defresi (Sukmono, 2008:3).

Dalam Islam, salah satu cara untuk menghilangkan perasaan tidak tenang dan tidak nyaman adalah dengan berzikir mengingat kepada Allah dalam arti yang luas. Berkaitan dengan zikir sebagai penenang jiwa, hal tersebut telah disebutkan di dalam Al-Qu'an dan hadis Rasulullah dalam berbagai redaksi dan maksudnya. Oleh karena itu, al-Qur'an telah memberikan pedoman bagi umat manusia dan memberikan solusi dari berbagai persoalan yang dihadapi oleh berbagai manusia termasuk kondisi psikologis yang tidak tenang dan labil, termasuk tuntunan islam agar manusia merasakan ketenangan dan kedamaian dalam hati, maka diperintahkan untuk berzikir kepada Allah Swt.

Dengan zikir dan doa, akan menumbuhkan sikap optimis dan percaya diri dan itulah dapat mengusir kegelisahan jiwa, bahkan yang hidup di Eropa dan Amerika sekalipun yang menganjurkan umat beragama untuk kembali mengingat Tuhan. Kongres Amerika beberapa waktu silam, sebagaimana dikutip oleh M. Quraish Shihab mengatakan, bahwa mereka mengajak masyarakatnya melakukan shalat, puasa dab bertaubat secara nasional karena meningkatnya kekerasan, perpecahan dan kerusahan dan ini akibat kita berpaling dari Tuhan. Zikir dapat mengembalikan jati diri manusia secara utuh yang terpenuhinya unsur jasmani dan rohani, zikir juga dapat 


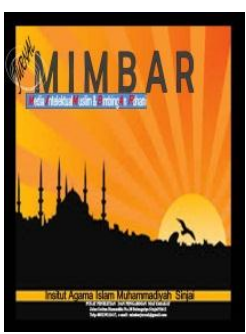

MIMBAR

Jurmal Media Intelektual Muslim dan Bimbingan Rohani

Volume 6, No. 1, 2020

P-ISSN: 2442-3217

E-ISSN: 2716-3806

Homepage : http://journal.iaimsinjai.ac.id/indeks.php/mimbar

mengembangkan potensi iman pada diri manusia yang akan memberikan nilai positif dalam kehidupan (Abdullah, 2002: 61).

Berkaitan dengan itu, tulisan ini akan membahas bagaimana hakekat zikir dalm perspektif islam bagaimana pengaruh zikir dapat membawa seseorang meraih ketenangan jiwa dan ketentraman batin.

\section{Metode}

Penelitian ini adalah penelitian kepustakaan (library research) dengan jenis kualitatif. Pengumpulan data dilakukan dengan menelusuri sumber-sumber primer maupun sekunder terkait dengan zikir dan ketenangan jiwa. Sumber primer dan sekunder tersebut didapatkan melalui buku-buku, artikel dalam jurnal, dan lainnya. Setelah data terkumpul, maka dilakukanlah analisa terhadap data tersebut dengan menggunakan content analysis. Hal ini dilakukan untuk menemukan apa sesungguhnya arti dari zikir dan ketenangan jiwa serta hubungan antara keduanya.

\section{Hasil dan Pembahasan}

\subsection{Pengertian Zikir}

Kata zikir dalam berbagai bentuknya ditemukan dalam Al-Qur'an tidak kurang dari 280 kali. Kata zikir pada mulanya dugunakan dalam bahasa Arab dalam arti sinonim lupa. Zikir juga pada mulanya berarti mengucapkan dengan tidak atau menyebut sesuatu. Makna ini kemudian berkembang menjadi "mengingat" karena mengingat sesuatu seringkali mengantar tidak menyebutnya. Demikian juga, menyebut dengantidak dapat mengantar hati untuk mengingat, lebih banyak lagi apa yang disebut itu.

Secara etimologi, perkataan zikir merupakan masdar (kata kerja benda) dan kata kerja "dzakara" yang artinya mengingat, memperhatikan, mengenang, mengambil pelajaran, mengenal atau mengerti (Manshur, 1990: 1507). Dalam kehidupan manusia, usur ingat sangat dominan karena merupakan salah satu fungsi intelektual. Namum dalam uraian ini perkataan zikir yang dimaksud adalah "dzikrullah" atau mengingat Allah.

Menurut Ibn Faris bin Zakaria, zikir mempunyai arti asal yaitu mengingat sesuatu dan antonim dari lupa, kemudian diartikan dengan mengingat dengan lidah atau 


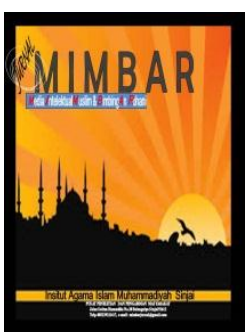

menyebut. Zikir juga di analogikan dengan "keluhuran" atau "kedudukan tinggi" (ala'la) kemuliaan atau kehormatan (Zakaria, 1987: 105).

Secara terminologi zikir yang dimaksud sebagaimana yang dilakukan oleh kalangan tasauf dan tarekat, prilaku zikir diperlihatkan hanya dalam bentuk "renungan" sambil duduk mengucapkan lafadz-lafadz Allah. Pengertian ini dapat dilihat sebagaimana uraian spencerTrimingham sebagaimana dikutip oleh Afif Ashori dalam buku dzikir demi kedamaian jiwa, memberikan pengertian zikir sebagai "Recollection, $a$ Spritual exercise designed to Render God's presence through-out one's being. The method employed rhythmical repetitive invocation of God's name" maksudnya ingatan atau suatu latihan spritual yang bertujuan untuk menyatukan kehadiran Tuhan seraya membayankan wujudnya, atau suatu metode yang digunakan untuk mencapai konsentrasi spritual dengan menyebut nama Tuhan secara ritmis dan berulang-ulang (Ansori, 2003: 16). Sementara itu Al-Kalabazi dikutibOleh Afif Anshori memberikan pengertian bahwa "zikir yang sesungguhnya adalah melupakan semuanya kecuali yang esa“. Juga dipertegas oleh Hasan al-Banna, Salah seorang tokoh Ikhwanul Muslimin di mesir menyatukan bahwa "semua apa yang mendekatkan diri kepada Allah dan semua ingatan yang menjadikan diri dekat dengan Allah maka itu disebut dzikir (Ansori, 2003: 17).

Dalam pengertian yang lebih luas dan rinci. Mu'jam Alfazh al-Qur'an memberikan empat pengertian dasar dari kata-kata Dzikir tersebut yaitu:

a. Mengucapkan dan menyebut nama Allah serta menghadirkan dalam ingatan.

b. Mengingat nikmat Allah dengan menghadirkan Allah dalam kehidupan kita dengan menjalankan kewajiban sebagai hamba Allah.

c. Mengingat Allah dengan menghadirkan-Nya dalam hati yang disertai dengan tadabbur, baik disertai ucapan, lisan atau tidak.

d. Allah Mengingat hambanya melalui pembalasan kebaikan kepada mereka dan mengangkat derajatnya (Majma, 1986: 437).

Dengan demikian dapat juga berarti mengingat Allah sebagai satu-satunya zat yang berhak untuk disembah. Berzikir berarti melakukan segala aktifitas yang bias membangkitkan ingatan akan keagungan, kebesaran dan kemuliaan Alla. Dengan zikir 


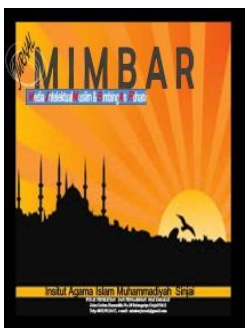

atau mengingat Allah maka Allah juga ankan ingat kepada ummat manusia sebagaima firman Allah swt dalam QS. al-Baqarah/2: 152:

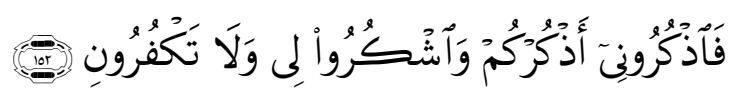

Terjemahnya:

Karena itu, ingatlah kamu kepada-Ku niscaya Aku ingat (pula) kepadamu, dan bersyukurlah kepada-Ku, dan janganlah kamu mengingkari (nikmat)-Ku (Departeman Agama, 2005: 323).

Dari beberapa pengertian tentang zikir, nampaknya zikir baru merupakan bentuk komunikasi sepihak antara mahluk dengan sang khalik saja. Akan tetapi lebih dari itu zikrullah bersifat aktif dan kreatif karena komunikasi tersebut bukan hanya sepihak melainkan bersifat timbal balik seperti yang dikemukakan oleh Imam al-Qazali, zikrullah berarti ingatan seseorang bahwa Allah mengamati seluruh tindakan dan pikirannya, dan itulah makna dari ayat diatas yang terdapat pada surah al-Baqarah ayat 152 (Ansori, 2003: 20).

Kata zikir secara umum dapat juga dipahami sebagai memelihara sesuatu karena tidak melupakan sesuatu berarti memeliharanya atau terpeliharanya dalam benaknya. Dari sini kata zikir juga dapat dipersamakan dengan menghafal, hanya saja penekanannya pada upaya memperoleh pengetahuan dan menyimpannya dalam benak, sedangkan zikir adalah menghadirkan kembali apa yang tadinya dilupakan dan hanya ada dalam benak. Maka zikir seperti inilah yang melahirkan zikir dengan hati sebagaimana juga zikir dengan lisan dalam arti menyebut.

Dengan demikian dapat disimpulkan bahwa segala aktivitas manusia baik lahir maupun bathin, lisan atau hati yang dimaksudkan untuk mengingat, menyebut dan mendekatkan diri kepada Allah dalam setiap waktu dan kesempatannya maka tergolong sebagai orang yang berzikir dan dengan zikir itu akan mengantarkan manusia kepada ketenangan dan kedamaian jiwa. Al-Qur'an menggambarkan bahwa kalimah tayyibah atau bacaan zikir yang tertanam kuat didalam hati akan memberikan kesadaran secara mendalam dan menjiwai seluruh prilaku sesorang serta bermuara pada moralitas yang tinggi (al-Akhlak al- karimah) dan pada akhirnya akan memberikan yang positif bagi jiwa atau rohani manusia berupa ketenangan batin atau jiwa sebagaiman firman Allah Swt. QS. ar-Rad/13: 28: 


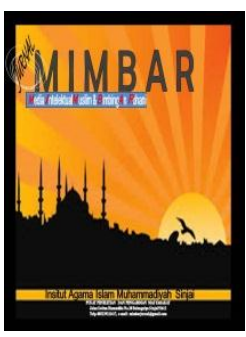

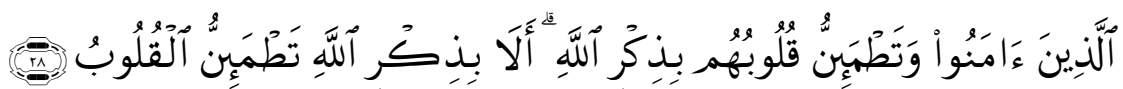

Terjemahnya:

(Yaitu) orang-orang yang beriman dan hati mereka manjadi tenteram dengan mengingat Allah. Ingatlah, hanya dengan mengingati Allah-lah hati menjadi tenteram (Departeman Agama, 2005: 373).

Ayat di atas memaparkan bahwa setiap hati orang yang beriman akan tenang dan tentram ketika berzikir kepada Allah. Hati mereka penuh dengan cinta sehingga ketika disebutkan nama Allah dan dibacakan ayat-ayat-Nya keimanan mereka bertambah. Lebih jauh para ahli tafsir ketika menafsirkan ayat ini misalnya Imam Muhammad Ibnu Ali Al-Syaukani memaparkan bahwa ketenangan dan ketentraman hati orang-orang yang beriman adalah dengan berzikir kepada Allah dengan lisan, mereka seperti membaca al-Qur'an, membaca tasbih, tahmid dan takbir atau dengan mendengarkannya. Allah menyebut al-Qur'an sebagai zikir dalam dalam firmannya: "Dan al-Qur'an ini adalah zikir (kitab) yang mempeunyai berkah yang telah kami turunkan” (QS alAnbiya: 50), juga firman Allah "Sesungguhnya kamilah yang menurunkan zikir alQur'an dan sesungguhnya kami benar-benar memeliharanya”, (QS. Al-Hijr: 9).

\subsection{Pengertian Ketenangan Jiwa}

Ketenagan berasal dari kata "tenang" dan kemudian diberi imbuhan ke-an, ketenangan secara etimologi berarti menatap, tidak gusar, yaitu suasana jiwa yang berada dalam keseimbangan sehingga menyebabkan seseorang tidak terburu-buru atau gelisah. Tenang juga berarti diam, tidak berubah-ubah, tidak gelisah, tidak susah, tidak gugup dan cemas betapa pun keadaan gawat, tidak tergesa-gesa” (Poerwadarminta, 2008: 342).

Sedangkan kata jiwa dalam bahasa inggris disebut psyche yang berarti jiwa, nyawa atau alat untuk berfikir (Irwanto, 1991: 3). Sedangkan dalam bahasa Arab jiwa seiring disebut dengan " al nafs" Oleh Imam al-Qazali dimaknai bahwa jiwa adalahsegala hakekat kejiwannya, itulah pribadi dan zat kejiwaannya (Al-Gazali, 1984: $13)$.

Jiwa adalah roh manusia yang ada dalam Ambu dan menyebabkan hidup. Jiwa yang dimaknai sebagai seluruh kehidupan batin manusia berupa perasaan, pikiran dan sebagainya. Jiwa dalam agama adalah adalah sebahagian dari kerohanian manusia yaitu 


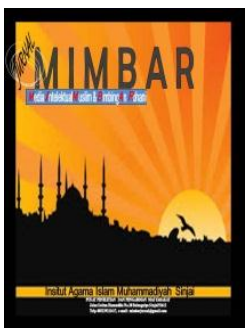

kesanggupan merasakan sesuatu. Seseorang dikatakan berjiwa jika sanggup mengalami, merasakan, berkemauan dan lain sebagainya. Dengan demikian jiwa yang dimaksud disini adalah segala hal yang meliputi dan dimiliki oleh manusia yang meliputi hati, pikiran dan perasaan.

Dalam psikologi, jiwa lebih dihubungkan dengan tingkah laku sehingga yang diselidiki oleh para psikologi adalah perbuatan yang dipandang sebagai gejala-gejala dalam jiwa. Teori-teori baik psikoanalisa, behavioralisme maupun humanisme memandang jiwa sebagai sesuatu yang berada dibelakang tingkah laku (Soemanto, 1988: 15).

Darajat mengemukakan bahwa orang yang tenang jiwanya itulah yang dianggap memiliki kesehatan mental atau psikis dengan beberapa ciri di antaranya:

a. Kesehatan mental adalah terhindarnya seseorang dari gejala-gejala ganguan jiwa (neurose) dan dari gejala-gejala penyakit jiwa (psychose).

b. Kesehatan mental adalah kemampuan untuk menyesuaikan diri sendiri dan dengan orang lain dan masyarakat serta lingkungan dimana ia hidup.

c. Kesehatan mental adalah pengetahuan dan perbuatan yang bertujuan untuk mengembangkan dan memanfaatkan segala potensi, bakat, dan pembawaan yang semaksimal mungkin sehingga membawa kepada kebahagiaan diri dari orang lain.

d. Kesehatan mental adalah terwujudnya keharmonisan yang sesungguh-sungguhnya antara fungsi jiwa, serta mempunyai kesanggupan menghadapi problem yang dihadapinya untuk melahirkan ketenangan jiwa dan kebahagiaan pada dirinya (Darajat, 1991: 12).

Sedangkan manusia yang memiliki ketenagan jiwa menurut Dr, Zakiyah Darajat, mulai dari tingkat yang paling ringan sampai tingkat yang paling parah sehingga mengara pada defresi dan kegilaan. Hal itu dapat dilihat dari beberapa segi yaitu:

a. Dari segi perasaan diantara ganguan perasaan yang disebabkan karena ketenangan mental adalah rasa cemas, gelisah, bimbang dan ragu.

b. Dari segi pikiran, gejala itu dapat dilihat berupa sering lupa, tidak dapat berkonsentrasi, kemampuan berfikir melawan, dan merasa pikirannya buntu. 


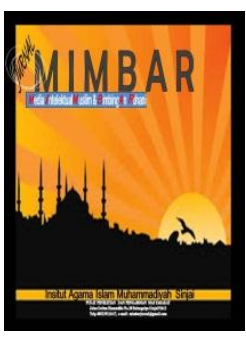

\section{MIMBAR}

Jurnal Media Intelektual Muslim dan Bimbingan Rohani

Volume 6, No. 1, 2020

P-ISSN: 2442-3217

E-ISSN: 2716-3806

Homepage : http://journal.iaimsinjai.ac.id/indeks.php/mimbar

c. Dari segi perilaku dan kelakuan, gejala yang Nampak adalah adanya penyimpangan-penyimpangan yang dilakukan sehingga menyebabkan dirinya dan orang lain menderita seprti tindak criminal, agresif (menyerang), deskruktif (merusak) dan lain-lain (Darajat, 1991: 17).

Di sisi lain bahwa ketenangan jiwa dapat dipengaruhi oleh dua faktor utama yaitu factor internal dan faktor eksternal. Faktor internal sangat dipengaruhi oleh tingkat keimanan dan ketaqwaan, sikap dalam menghadapi problema hidup, rutinitasnya dalam berzikir dan kondisi jiwa lainnya yang stabil, memiliki rasa syukur-syukur dan sabar, tidak mudah putus asah dan mudah beradap tasi dengan orang lain dengan berbagai kebahagiaan. Sedangkan factor eksternal atau kondisi luar yang melingkupi seseorang seperti kondisi lingkungan, tingkat pendidikan, keadaan ekonomi, dan keadaan sosial, politik dan faktor lainnya. Namun dari kedua faktor tersebut, yang paling menentukan adalah faktor internal yang akan mengantar manusia meraih ketenangan jiwa (Darajat, 1991: 23).

Memang jika dilihat, kebanyakan orang-orang yang terkena kekuatan mental (mental disorder), adalah mereka yang jauh dari norma-norma agama, sebaliknya orang yang senantiasa mengingat kepada Allah akan mampu mengontrol dan mengendalikan segala pikiran, emosi, dan perbuatannya, sehingga apabilah tidak meraih apa yang diinginkan, tidak akan terganggu jiwanya.

\subsection{Peranan Zikir dalam Meningkatkan Ketenangan Jiwa}

Berbicara tentang peranan zikir dalam meningkatkan ketenangan jiwa, maka hal itu tidak terlepas dari janji Allah SWT tentang faedah dan manfaat berzikir kepada-Nya sebagaimana firman Allah QS. ar-Ra'ad/13: 28:

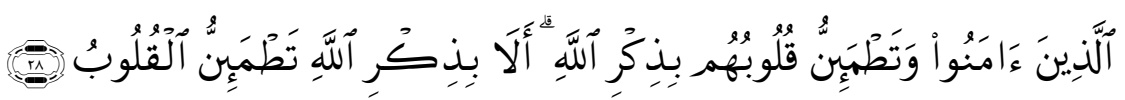

Terjemahnya:

(Yaitu) orang-orang yang beriman dan hati mereka manjadi tenteram dengan mengingat Allah. Ingatlah, hanya dengan mengingati Allah-lah hati menjadi tenteram (Departeman Agama, 2005: 373).

Dari ayat diatas dipahami bahwa zikir dapat membawa pengaruh pada ketenangan jiwa, maka hal ini dapat dijelaskan dengan berebagai pendekatan termasuk diantaranya pendekatan secara psikologi. Secara psikologi dapat dimaknai bahwa hasil dari 


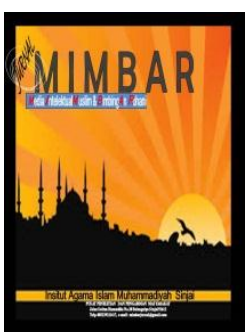

perbuatan mengingat Allah (zikrullah) ini dalam alam kesadaran akan berkembang menjadi sebuah penghayatan akan kehadiran Allah dalam setiap gerak-geriknya, ia begitu yakin akan pengawasan dan penjagoan Allah sehingga ia tidak merasa sendiri menjaalani kehidupan ini.

Pendekatan lain yang dapat dijadikan bahwa zikir sangat besar peranannya dalam meningkatkan ketenangan jiwa adalah pendekatan ilmiah darp pandangan para ahli kesehatan, baik kesehatan fisik, maupun kesehatan mental. Dengan bukti ilmiah terkait rahasia zikir sebagai penenang jiwa dan berfungsi sebagai terapi, dapat dibuktikan dengan pendekatan ilmu medis, bahwa dalam otak manusia terdapat zat kimiawi yang secara otomatis keluar ketika seseorang berzikir. Zat itu beragama" endorphin" yang berfungsi untuk menenangkan otak, sebagaimana mortin mampu menenangkan otak, bedanya mortin berasal dari luar tubuh, sedang zat endorphin berasal dari dalam tubuh (Cahyo, 2011: 98).

Penjelasan ilmiah yang lain seperti terungkap dari penelitian senang dokter spesialis saraf dari rumah sakit satya Negara, suntur, arman yurisaldi saleh, mengungkapkan bahwa zikir mampu menyehatkan saraf. Hal itu terbukti setelah ia melakukan penelitian terhadap pasien-pasien yang ia tangani yang mengalami gangguan saraf, seperti penderita Alzheimer atau stroke. Ternyata pasien yang suka berzikir mengalami perbaikan lebih cepat dibandingkan pasien yang tidak suka berzikir. Dengan rutinitas mereka berzikir kalimat "La Ilaha illa Allah" dan "Astagafirullah al-adzim" dapat menghilangkan nyeri dan menumbuhkan ketenangan serta kestabilan saraf bagi penderita, sebab dua kalimat zikir tersebut terdapat huruf-huruf yang apabilah di ulangulang dan dilafalkan dengan bersuara akan dapat mengeluarkan karbondioksida dari otak saat udara dihembuskan keluar dari mulut.

Dari penelitian ilmiah diatas tentang al_qur'an sebagai media zikir yang dapat mendatangkan ketenangan jiwa dan kerenangan batin semakin memperkuat keyakinan kita akan kebenaran firman Allah swt bahwa diantara fungsi diturungkannya Al-Qur'an adalah sebagai obat (syifa) dan Rahmat sebagaiman telah dijelaskan di dalam Al-Qur'an QS. al-Isra/17: 82: 


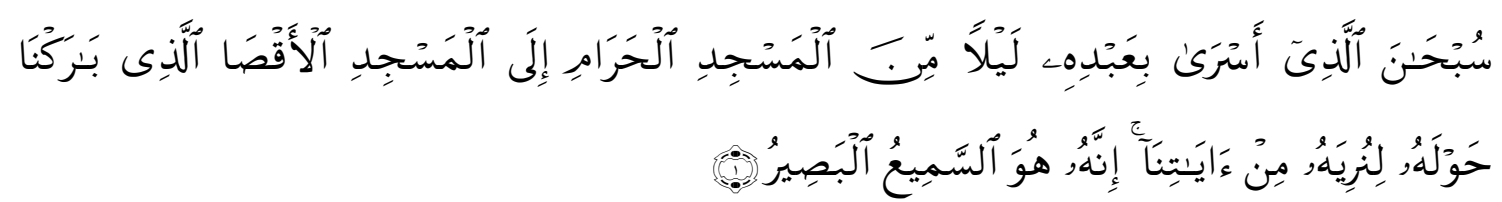

Terjemahnya:

"Dan Kami turunkan dari Al Quran suatu yang menjadi penawar dan rahmat bagi orang-orang yang beriman dan Al Quran itu tidaklah menambah kepada orang-orang yang zalim selain kerugian”. (Departeman Agama, 2005: 291).

\section{Kesimpulan}

Dari uraian diatas dapat disimpulkan bahwa zikrullah yakni berzikir kepada Allah disetiap waktu dan kesempatan dengan berbagai bentuk dan materi zikir baik zikir dengan mendirikan shalat, membaca Al-Qur'an dan membaca kalimah tayyibah serta memandan dan mentadabburi fenomena alam raya, telah terbukti akan memberikan manfaat yang besar bagi manusia baik manfaat disegi kesehatan psikis atau jiwa dan pada akhirnya akan memberikan pengaruhnya yang positif berupa meningkatnya ketenagan jiwa dan menghadirkan ketentraman batin terutama bagi mereka yang melakukan aktivitas zikir dengan khusyu dan ikhlas semata-mata karena Allah Swt. Dan ini semakin membuktikan bahwa Islam telah memberikan saksi dan terapi yang tepat dalam mengatasi kegelisahan batin dan kegalauan jiwa bahwa dengan zikirullah hati dan jiwa menjadi tenang dan tentram.

\section{Daftar Pustaka}

Abdullah, Taufiq. (2002). Ensiklopedia, Tematis, Tematis Dunia Islam. Jakarta: Ikhtiar Baru.

Al-Ghazali, Imam. (1984). Terjemahan; Ajaib al-Qulub (Keajaiban Hati) . Jakarta: Tirta Mas.

Asnhori, M. Afif. (2003). Zikir Demi Kedamaian Jiwa (Solusi Tasauf dalam Mengatasi Problem Modern). Yogyakarta: Pustaka Pelajar.

Cahyo, Agus N. (2011). Penjelasan Ilmiah Tentang Dasyatnya Manfaat Harian (Untuk Kesehatan Jiwa dan Fisik). Yogyakarta: Diva Press.

Darajat, Zakiyah. (1991). Islam dan Kesehatan Mental. Jakarta: Gunung Agung. 


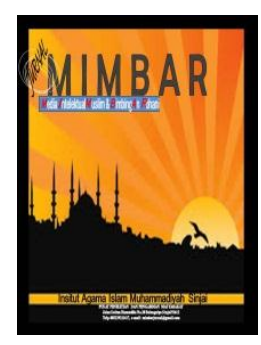

MIMBAR

Jurnall Media Intelektual Muslim dan Bimbingan Rohani

Volume 6, No. 1, 2020

P-ISSN: 2442-3217

E-ISSN: 2716-3806

Homepage : http://journal.iaimsinjai.ac.id/indeks.php/mimbar

Departemen Agama RI. 2005. Al Quran dan Terjemahannya. Jakarta: Al Huda Kelpompok Gema Insani.

Haryanto, Alfandi \& Munir Syamsul. (2008). Energi Zikir Menentramkan Jiwa Membangkitkan Optimisme. Wonosobo: Percetakan Hamza.

Irwanto, dkk. (1991). Psikologi Umum. Jakarta: PT. Gramedia Pustaka Utama.

Majma. (1986). Al-Lughah al Arabiyah \& Mujam Al-Fazh al-Qur'an. Kairo: Al Hay'ah al-Mishriyah.

Manshur, Ibn. (1990). Lisan al-Arab. Bairut: Dar al-Maarif.

Poerwadarminta, W.S. (2008). Kamus Besar Bahasa Indonesia. Jakarta.: Balai Pustaka.

Soemanto, Westy. (1988). Pengantar Psikologi. Jakarta: Bina Aksara.

Zakaria, Ibn Faris Bin. (1987). Maqaays al-Lughah. Bairut: Dar al-Maarif. 